\title{
GALLOGRAECI AND ELEPHANTS AT MEGARA
}

\begin{abstract}
The aim of this paper is to re-examine the arguments concerning the question whether Antiochos I did indeed send military aid to Antigonos Gonatas during the Chremonidean War. The assumption rests on three pieces of evidence - the inscription of Brikkon, the elephants at Megara and the presence of Celtic troops from Gallograecia. Since it has been proven long ago that the inscription of Brikkon has been misunderstood and is from a later date, there is nothing more to be added in this instance. As for the elephants, the argument is far less convincing once it is realized that in the years prior to the Chremonidean War Antigonos already had some in his army, and therefore there is no need to assume that the ones he deployed at Megara were sent from Antiochos I. The argument becomes even less persuasive if we take into account that the situation in Asia Minor was far less settled than once thought, and especially since there are some indications that at the time Antiochos did not even had a huge number of elephants in his army and consequently seems doubtful whether he would have been ready to further weaken his elephant corps by sending some of them to Antigonos. Similarly, the mention of troops from Gallograecia, though convincing at first glance, is far less persuasive on closer examination. Considering the problems with Justin's description, his authority without the support of the other two arguments should not be accepted at face value. On top of that, since on another occasion he uses the name to denote not the Celts from Asia Minor but from the Balkans, the possibility that we are dealing with Celts from the Balkans can not be ruled out. In conclusion, though nothing can be said with absolute certainty, until some new evidence emerges, there is not a single compelling argument that Antiochos took part in the Chremonidean War.
\end{abstract}

Only a few years after he managed to finally rid himself from Pyrrhos, Antigonos Gonatas was faced with a new challenge. For a new coalition was created, led by Ptolemy II, Sparta and Athens and directed against the Macedonian king. Unlike during the struggle with Pyrrhos, this time his throne was not threatened, yet the situation was no less serious, for all of his possessions in Greece were at stake. Although faced with various problems on multiple fronts especially at the start of the hostilities, in the end Antigonos managed to prevail in this prolonged conflict, 
known as the Chremonidean war. His victory had a lasting effect on the affairs in Greece, for the Athenian power, diminished as it already was, was crushed once and for all, while the Spartan ambitions were curbed for a considerable time. At the same time, as a result of Antigonos' victory the spread of Ptolemaic influence in continental Greece was thwarted. Therefore this war and its outcome was the most important event in Greece, and certainly one of the most important in Hellenistic world in general, in the sixties.

Yet in comparison to its importance, our knowledge of this war, a war that as it turned out was to be the only prolonged direct clash between the Antigonids and the Ptolemies, is disproportionately limited. Indeed we know more about this war than about many other events from this period. However, considering how little we know about the so-called First Syrian war, or the wars of Antiochos I against the Northern coalition, and later against the Galatians, the fact that we are better informed about the Chremonidean war is little more than a consolation. Since all the major historical sources for the period are all but lost, this is hardly surprising. After all, even the duration of the war was a matter of a long debate, though it does seem that an opinio communis is finally forming for 268/7 as the year of Peithidemos, and 263/2 as the year of Antipatros. Nonetheless, a number of important questions, such as the activities of Patroklos, of Areus, the sequence of events and so on, remain open for discussion.

One such problem is the question of the supposed involvement of Antiochos I on behalf of Antigonos. It is the reconsideration of this assumption that is the subject of this paper. The theory that Antiochos I did indeed send some help to Antigonos rests on combining three pieces of evidence - one inscription from Maroneia, an undated information about Antigonos' use of elephants against the Megarians, and a highly problematic passage in Justin concerning a mutiny among Antigonos' mercenaries from Gallograecia. Even though interconnected, for sake of clarity I shall discuss each of them separately.

1. The relevant inscription was first linked to the Chremonidean war by C. Bradford Welles. ${ }^{1}$ The inscription is an epigram in honor of one Brikkon from Apameia, son of Ateuristos, who led a body of Galatians who perished in a battle against Are(u)s. ${ }^{2}$ Considering we are dealing with contemporary evidence, C. B. Welles rightly emphasized that this is the most important and at the same

${ }^{1}$ C. B. Welles (1970): „Gallic Mercenaries in the Chremonidean War“, Klio 52, 577-90.

${ }^{2}$ SEG 24.637. 
time most revealing piece of evidence for the whole theory. As he concludes, Brikkon could hardly have been recruiting soldiers in Asia Minor without at least the tacit approval of Antiochus I. ${ }^{3}$ At the same time by identifying the Are(u)s from the inscription with the Spartan basileus Areus I, he concluded that these Gauls met their end while fighting for Antigonos during the Chremonidean war. This reconstruction has been accepted among others by E. Will and F. W. Walbank, and has recently been reiterated by J. L. O'Neil. ${ }^{4}$ It is quite unfortunate that it found its way in the influential works of both E. Will and F. W. Walbank, for only one year after the publication of Welles' article, Y. Grandjean convincingly refuted the most relevant aspects of the theory. ${ }^{5}$

First off, the Ares mentioned in the inscription is not the Spartan basileus, but the god of war, that is "Apns is just a synonym for $\pi$ ó $\lambda \varepsilon \mu \rho \varsigma$. What we are dealing with here is a poetic expression that those Gauls were killed in battle. ${ }^{6}$ To make things even worse, the inscription does not even belong to the first part of the $3^{\text {rd }}$ century, but to the early $2^{\text {nd }}$ century. Brikkon probably took part in the second Thracian expedition of Antiochos III in $195 .{ }^{7}$ What was supposed to be the most compelling evidence for the involvement of Antiochos I in the Chremonidean war has no bearing on the question whatsoever.

2. The second argument is based on a piece of information preserved in Polyaenus and Aelian. ${ }^{8}$ According to the story, when Antigonos was besieging Megara and brought his elephants to the fore, the Megarians unleashed on them pigs smeared with liquid pitch to the effect that the elephants panicked and broke rank. ${ }^{9}$ According to J. O'Neil, the mention of the elephants in the army of Antigonos is an even stronger evidence for the Seleucid sup-

${ }^{3}$ Welles 1970: 483, 488f.

${ }^{4}$ E. Will (1979): Histoire politique du monde hellenistique, t. $1^{2}$, Nancy, 227; F. W. Walbank (1988), in N. G. L. Hammond \& F. W. Walbank, A History of Macedonia vol.3, Oxford, 282 n.1; J. L. O'Neil (2008): „A re-examination of the Chremonidean War", in P. McKechnie \& P. Guillaume (edd.), Ptolemy II Philadelphus and his World, Leiden-Boston, 80.

${ }^{5}$ Y. Grandjean (1971): „Note sur une épigramme de Maronée“, $B C H$ 95.1, 283-94.

${ }^{6}$ Grandjean 1971: 286ff.

7 J. Ma (1999): Antiochos III and the Cities of Western Asia Minor, Oxford, 91. Grandjean 1971: 293, prefers to date it to 194 during a third Thracian expedition of Antiochos III.

${ }^{8}$ Polyaen., Strat., 4.6.3; Ael., Nat. Anim., 11.14, 16.36.

9 Aelian tells a similar story for a battle between the Romans and Pyrrhos (Nat. Anim., 1.38). 
port during the war. ${ }^{10}$ At first glance, this assumption does seem sound. Indeed, where could Antigonos acquire elephants if not from Antiochos I? However, things are not as simple as they seem.

Before we proceed though, one more issue needs to be emphasized. Since both Polyaenus and Aelian are quite vague in their descriptions, there is no way to ascertain when did Antigonos besiege Megara. As H. Heinen, points out, it is impossible from these descriptions to determine the larger context in which the siege of Megara took place. ${ }^{11} \mathrm{~W}$. W. Tarn for one, preferred to place the capture of Megara ca. $270,{ }^{12}$ as does F. Walbank, who places the storming of Megara between 272 and $268 .{ }^{13}$ On the other hand, H. Heinen thinks that Antigonos took Megara during the Chremonidean war. ${ }^{14}$ Though Heinen's dating does seem somewhat preferable, there is no way to be certain, and the question must remain unanswered. The implications for the theory that Antiochos I helped Antigonos during the Chremonidean war are quite obvious - if the siege of Megara took place prior to the war, than the presence of the elephants is irrelevant. Again, there is no way to resolve this problem with certainty, so both options must remain a possibility; however this chronological uncertainty should not be forgotten when discussing the presence of the elephants at Megara.

Be that as it may, for the sake of the argument let us proceed under the assumption that Megara did indeed fell during the Chremonidean war and return to the question of the elephants. If we are to conclude that these elephants were in fact sent by Antiochos I, first of all it has to be proven that Antigonos had none in his army prior to the Chremonidean War. For if they were frequently part of his army in the period preceding the war, their presence at Megara would come as no surprise, while the assumption that he received them from Antiochos I during the war would be superfluous. Somewhat surprisingly, the elephants are indeed mentioned as part of Antigonos' army in the seventies.

During the initial negotiations prior to the battle of Lysimacheia, in a vain attempt to simultaneously impress and frighten

${ }^{10}$ O’Neil 2008: 81. cp. Welles 1970: 489; B. Niesse (1899): Geschichte der griechischen und makedonischen staaten seit der schlacht bei Chaeronea, t.2 (281188), Gotha, 235.

${ }^{11}$ H. Heinen (1972): Untersuchungen zur hellenistischen Geschichte des 3. Jahrhunderts v. Chr. Zur Geschichte der Zeit des Ptolemaios Keraunos und zum Chremonideischen Krieg, Wiesbaden, 171.

${ }^{12}$ W. W. Tarn (1913): Antigonos Gonatas, Oxford, 286.

${ }^{13}$ Walbank 1988: 270.

${ }^{14}$ Heinen 1972: 170ff. 
the Celts, among all the other riches, Antigonos also ordered for the elephants to be put on display. ${ }^{15}$ Admittedly, Justin is not one of the more reliable sources, and his description of the battle of Lysimacheia is filled with inconsistencies. ${ }^{16}$ If this was the only instance were the elephants are mentioned in Antigonos' army, it would have been quite suspicious and unreliable argument to build upon the theory concerning their presence prior to the siege of Megara.

However, there is another piece of information that is no doubt far more reliable. During the battle between Antigonos and Pyrrhos in 274, the Epeirote king managed to encircle the elephant corps in Antigonos' army, and as a consequence they changed sides, soon to be followed by the Macedonian infantry. ${ }^{17}$ Though temporarily deprived of the elephants, after the final victory against Pyrrhos at Argos in 272, Antigonos undoubtedly got them back, for Plutarch is quite explicit that after the fighting was over Antigonos took over the remnants of Pyrrhos' army. ${ }^{18}$ That during this final campaign Pyrrhos had elephants, much to his own detriment as it turned out, is a well known fact. ${ }^{19}$ This is especially important since Plutarch, despite the overly dramatic and pathetic elements in his narrative, was mainly following a firstrate source, most probably Hieronymos of Cardia. ${ }^{20}$ Unless we are prepared to imagine that all of them died between 272 and 267 when the actual fighting in the Chremonidean war began, it seems safe to assume that at the start of the war Antigonos did have elephants in his army.

As to where did Antigonos acquired them, the answer partly rests on whether we should accept Justin's description of the battle of Lysimacheia, for if not for that piece of information the solution is clear - the elephants that Antigonos employed against Pyrrhos in 274 were the remnants of the force commanded by Ptolemy Keraunos. As we know from Justin, among the other forces that Keraunos gave to Pyrrhos for his Italian expedition were a

15 Just., 25.1.3-6.

${ }^{16}$ On the problems concerning Justin's description see Walbank 1988: $256 \mathrm{f}$.

${ }^{17}$ On the battle at the Narrows Plut., Pyrr., 26.5-9. cp. Paus., 1.13.2; Diod., 22.11.1; Ampel. 28.3; Trog., Prol., 25; Just., 25.3.5-6. see P. Lévèque (1957): Pyrrhos, Paris, 561ff., though his identification of $\tau \dot{\alpha} \Sigma \tau \varepsilon v \grave{\alpha}$ with the place of the famous battle between T. Flamininus and Philip V is not to be accepted.

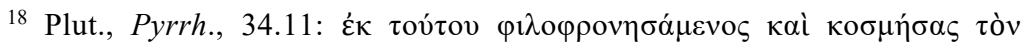

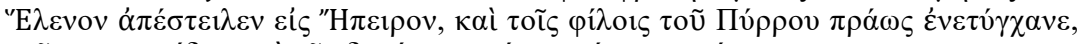

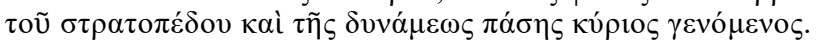

${ }^{19}$ For a detailed account of the battle at Argos, with analysis of the sources see Lévèque 1957: 613ff.

20 Tarn 1913: 448f.; Lévèque 1957: 614f. 
number of elephants. ${ }^{21}$ True, the numbers Justin gives does seem somewhat high, and not only for the elephants but for the cavalry as well, and perhaps Plutarch is to be followed here. ${ }^{22}$ In any case, whatever their number, Pyrrhos had an elephant corps with him in Italy. That Keraunos kept at least part of the force with him is clear from the description of his disastrous clash with the Celts, since he went in battle riding an elephant. ${ }^{23}$ These elephants were probably the ones that Seleukos I brought with him, which Keraunos took over after assassinating his benefactor. Antigonos took the remnants of this elephant corps when he finally became king in Macedonia. So far things are clear.

However, the presence of elephants in Antigonos' army at the battle of Lysimacheia remains a problem, for I do not see how he could have managed to get his hands on Keraunos' corps before he took control over Macedonia. Whatever number of elephants, if any at all, Demetrios Poliorketes might have had, he must have lost them when he was forced out of Macedonia by Lysimachos and Pyrrhos. ${ }^{24}$ So where did these elephants came from? One solution would be to simply ignore the information of Justin, and considering how garbled his description of the battle of Lysimacheia is, this may be the reasonable approach. But if we are to save the information of Justin, then I believe that the only solution is to assume that Antigonos received some elephants from Antiochos I. We know that for a while Antigonos was at war with Antiochos I, and the operations took place probably in Asia Minor, but perhaps in Thrace as well. Nothing is known about the course of the war, nor about its duration, but it seems that a peace was concluded in $278 .{ }^{25}$ The peace was reinforced by the marriage between Antigonos and his niece Phila who was Antiochos' halfsister and stepdaughter. ${ }^{26}$ If Antigonos did indeed have elephants before the battle Lysimacheia, I would assume that he obtained them as part of this agreement with Antiochos I in 278. Of course,

${ }^{21}$ Just., 17.2.14. $c p$. Plut., Pyrr., 15.2. Plutarch does not mention that Pyrrhos received any forces from Keraunos, but it is hard to see from where else he could have acquired the elephants.

22 Justin says that Keraunos gave him 50 elephants, but Plutarch mentions only 20 . Though some attempts have been made to reconcile the numbers, Plutarch is probably to be followed here (but see Walbank 1988: 246 n.4; Lévèque 1957: 278 n.2).

23 That Keraunos was fighting on an elephant is mentioned by Memnon, FGrH 434 F 8.8 .

${ }^{24}$ cp. Tarn 1913: 286 n.29.

${ }^{25}$ On the problems concerning this war see Walbank 1988: $250 \mathrm{f}$.

26 see J. Seibert (1967): Historische beiträge zu den dynastischen verbindungen in hellenistischer zeit, Wiesbaden, $33 \mathrm{f}$. 
we need not assume that it was a substantial number of elephants, more probably it would have been a small token force. If a few elephants were a price to pay to get Antigonos out of the picture while trying to deal with the Northern coalition, then it was not a bad bargain for Antiochos I. However this is a purely conjectural reconstruction that can not be supported by any source, and can rather be seen as a desperate attempt to save something that perhaps can not be saved. In the end, the question of the elephants at Lysimacheia does not affect the main problem concerning their presence at Megara. Whether we decide to believe that Antigonos had elephants at Lysimacheia or not, which again may be the wiser course, the fact is that they were part of his army in 274 , and again after 272 .

At the same time, none of the scholars who accept that the elephants were send from Antiochos I, seem to ask the question whether, even if he wanted to, he could afford to do so. The first decade of his reign was filled with external threats and constant fighting in an attempt to preserve the empire of his father and consolidate the Seleucid rule in Asia Minor, ${ }^{27}$ and things got even more complicated after the arrival of the Celts. Over the last few decades the date for the famous "Elephant victory" of Antiochos I, which brought an end to the Celtic terror in Asia Minor has been moved from the mid-seventies to the end of the decade, or even the beginning of the sixties. If this date is to be accepted, then the sending of elephants only a year or two after the hard won battle would seem quite improbable. Yet, since this the date of the battle remains uncertain, ${ }^{28}$ this must remain a speculation. But no matter when it is dated, the traditional view, that after this crushing defeat the Celts settled down and remained quiet for the next few decades, seems too neat and tidy. In fact it does seem that even in the sixties there were additional troubles and the situation in Asia Minor was far from settled, that is the "Elephant Victory" did not had the lasting effect as was usually thought. ${ }^{29}$ Things might have been even more chaotic if we accept that there was no "Elephant Victory" at all, ${ }^{30}$ nor that the Celtic tribes presented a single and unified political entity that could be dealt with

${ }^{27}$ see Will 1979: 135ff.; S. Sherwin-White \& A. Kuhrt (1993): From Samarkhand to Sardis. A new approach to the Seleucid empire, Berkeley-Los Angeles, $29 \mathrm{ff}$.

${ }^{28}$ For a discussion with extensive bibliography see A. Coşkun (2012): „Deconstructing a Myth of Seleucid history: the so-called "Elephant Victory" revisited", Phoenix 66.1/2, 59ff.

${ }^{29}$ H. Heinen (1988): „The Syrian-Egyptian Wars and the new kingdoms of Asia Minor", in $C A H^{2}$ VII.1: 423.

${ }^{30}$ This has been argued quite persuasively by A. Coşkun 2012: $61 \mathrm{ff}$. 
en bloc. ${ }^{31}$ Moreover, the Celts were not the only problem Antiochos I had to deal with - there were a number of independent rulers in Asia Minor, not all of whom were well disposed towards the Seleucids. If so, one can not but wonder whether Antiochos I would have deemed it prudent to weaken his elephant corps by sending a number of them to Antigonos. Admittedly, the sources for the second part of Antiochos' reign are quite scarce, ${ }^{32}$ so one can not press this argument too far. Far all we know, the second part of his reign, until the rise of the pergamene threat, passed in relative peace. ${ }^{33}$

Yet, there is still another reason why Antiochos may not have been in position to send elephants to Antigonos. Perhaps impressed by the 500 that Seleukos I acquired from Chandragupta, we tend to assume that the Seleucids at all times had a large number of elephants at their disposal. However, for all their physical strength, they were not invulnerable, nor were they immune to disease and exhaustion. Coupled with the fact that their life expectancy was much shorter when kept in captivity, we may wonder how many of these 500 elephants were left alive towards the end of Seleukos' reign. ${ }^{34}$ True, for the period following the battle of Ipsos we have no information about the exact number of elephants in the Seleucid army. However, the fact that in 273, during the first Syrian War Antiochos I expected and received a reinforcement of 20 elephants that were send from Bactria via Babylonia, ${ }^{35}$ probably indicates that by that time the elephant corps in the Seleucid army was not as numerous as one might imagine. ${ }^{36}$ The same impression is conveyed from Lucian's description of the "Elephant Victory". ${ }^{37}$ Now, as mentioned before, the "Elephant Victory" may not have happened at all and was a figment of Lucian's imagination; and even if it wasn't, his description of the battle is practically worthless. However, the peculiar number of only 16

31 A. Coşkun (2004): „Die tetrarchische Verfassung der Galater und die Neuordnung des Ostens durch Pompeius (Strab. geogr. 12,5,1 / App. Mithr. 560), “ in H. Heftner \& K. Tomaschitz (edd.), Ad fontes! Festschrift für Gerhard Dobesch zum fünfundsechzigsten Geburtstag am 15. September 2004. Vienna. 687-711 (non vidi).

32 see Will 1979: 150f.

${ }^{33}$ For this view see S. Sherwin-White \& A. Kuhrt 1993: 36f. $c p$. R. M. Errington (2008): A History of the Hellenistic World, Oxford, 117ff.

34 see B. Bar-Kochva (1979): The Seleucid Army. Organization and tactics in the great campaigns, Cambridge, 78f., who assumes that few if any at all of the original 500 were still alive by 285 .

35 AD I, no.-273B. cp. T. Boiy (2004): Late Achaemenid and Hellenistic Babylon, Leuven-Paris-Dudley, 141.

\footnotetext{
${ }^{36}$ see Bar-Kochva 1979: 78.

${ }^{37}$ Luc., Zeux., 8-12.
} 
elephants does seem to fit in well with the impression that at this point Antiochos I did not have a great number of elephants. Of course, we need not insist that these were all that Antiochos had, but at the same time it does show, I believe, that we can forget about the huge number of elephants that Seleukos at one point had at his disposal. Under such circumstances, with their number severely reduced, it does seem doubtful whether Antiochos I would have been prepared to further weaken his elephant corps by sending some of them to Antigonos.

From all that was said, I believe that two conclusions could be drawn. First, the positive evidence for the presence of elephants in Antigonos' army in the years prior to the Chremonidean War makes the assumption that he received those elephants from Antiochos I superfluous. Second, the unsettled state of affairs in Asia Minor, coupled with the likelihood that Antiochos I did not even possess a great number of elephants at the time, makes the assumption even less probable.

3. The last piece of evidence comes from Justin, who describes how at one point during the Chremonidean War Antigonos was unexpectedly faced with a new enemy - an army from Gallograecia. Leaving a cover force against Patroklos and Areus I, he proceeded with the main army against these Gallograeci. Infuriated by the unfavorable omens, they decided the appease the gods by sacrificing their own wives and children. Alas, even this act of desperation did not help - pursued by the furies for their hideous crime, they all perished in the ensuing battle. ${ }^{38}$

Obviously, not much can be made from this sensational description. ${ }^{39}$ We seem to be dealing with yet another example of demonization of the brutal and savage Galatians - a picture not infrequent in the ancient sources, that rarely conforms to reality. ${ }^{40}$ Without any additional corroborating evidence one is almost tempted to discard the whole story. If anything is to be salvaged at all, then we can accept that at some point during the Chremonidean War Antigonos was faced with an army of Gallograeci that he managed to defeat. Fortunately two pieces of information, not even mentioned by Justin, are preserved by Trogus, who says that these Celts were defectors from Antigonos' army and that they were defeated at Megara. ${ }^{41}$

${ }^{38}$ Just., 26.1-6.

${ }^{39}$ pace Welles 1970: 487f.

${ }^{40}$ For the stereotypical presentation of the Galatians in the sources see S. Mitchell (2003): "The Galatians: Representation and Reality", in A. Erskine (ed.), A Companion to the Hellenistic World, Oxford, 280-93.

${ }^{41}$ Trog., Prol., 26. 
Interestingly enough, C. B. Welles who relying on the epitaph of Brikkon assumed that there were Celts sent from Antiochos I, thought that these Gallograeci were actually a mixed body of Greek and Celtic mercenaries send by Ptolemy II. ${ }^{42}$ However, there is no need for such an assumption. The names Gallograecia and Gallograecus, though rare in comparison to the other names applied to the Celts or the lands they inhabited, is attested well enough and its meaning is quite clear - it signifies almost exclusively the territory inhabited by the Celts in Asia Minor. ${ }^{43}$ Does this mean that finally we have at least one concrete piece of evidence that a body of Celts from Asia Minor was sent to Antigonos, as some scholars think? ${ }^{44}$ Once more I believe that there is another way to explain Justin's expression.

To begin with, not only is the name Gallograecia undoubtedly a Roman creation, ${ }^{45}$ but seems to be a late one as well, the earliest attested occurrence being in a fragment from an oration by $\mathrm{C}$. Memmius from $66 \mathrm{BC}^{46}$ Naturally the loss of the earlier roman historians prevents us from establishing exactly at what time did the word first appear, but it would be surprising if it was earlier than the opening decades of the $2^{\text {nd }}$ century, when the Romans got more involved in the affairs of Asia Minor, especially after the campaign of Cn. Manlius Vulso in 189. True, the form $\Gamma \alpha \lambda \lambda o-$

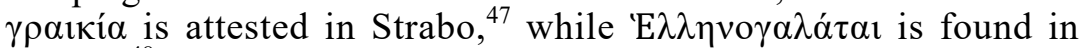
Diodor, ${ }^{48}$ but since we are dealing with later historians it seems safe to assume that both forms were created under the influence of the Roman Gallograecia. ${ }^{49}$ At the same time, it seems that the Greeks did not create a name for the Celts in Asia Minor as constrict as Gallograeci was. Though the names Galatai/Galatia are usually associated with the Celts in Asia Minor, they are not used exclusively - Galatia, just to cite few examples, can also signify

42 Welles 1970: 488.

43 e.g. Caes., Bell. Civ., 3.4.5; Cic., De Harusp., 28; Liv., 38.17.45-6; Flor., 1.27.3. I have made no attempt to collect all the examples where this name is used.

${ }^{44}$ Will 1979: 227; O’Neil 2008: 80.

${ }^{45}$ W. Heckel (1997): "Introduction, pt.2" in Justin, Epitome of the Philippic History of Pompeius Trogus. Books 11-12: Alexander the Great, (Translation and appendices by J. C. Yardley; Commentary by W. Heckel), Oxford, 28 n.70.

${ }^{46}$ Memm., orat 5. J. Briscoe (2008): A Commentary on Livy, Books 38-40, Oxford, 58.

${ }^{47}$ Strab., 12. 566C.

${ }^{48}$ Diod., 5.32.5.

49 cp. F. Papazoglu (2007): “Хеленизовани варвари у Страбоновој „Географији“", in F. Papazoglu, Iz istorije antičkog Balkana. Odabrane studije, Beograd, 266 n.6. 
the land of the Scordisci, ${ }^{50}$ Galatai can refer to the Celtic tribes in Gaul, ${ }^{51}$ while Polybios seems to use the Keltoi and Galatai indiscriminately, ${ }^{52}$ though it should be noted that he never uses Keltoi for the tribes in the Balkans or Asia Minor. ${ }^{53}$ But the problem with the naming of the Celts in the classical sources is known all too well, and for our present purposes there is no need to explore it any further. The aim was simply to point out that it seems highly unlikely that Trogus found is his source(s) a name closely corresponding to Gallograecia. ${ }^{54}$

Since Galatia can obviously refer to various territories inhabited by the Celts, is it possible that Trogus might have misunderstood his source? Admittedly this seems rather improbable since the name Gallograecia/Gallograeci is always used properly by the Latin authors. ${ }^{55}$ As mentioned before the name is relatively rare and is used by Trogus only once, in the prologue to the $34^{\text {th }}$ Book, and refers to the war between the pergamene king Eumenes II and the Gallograeci. As for the prologue of the $26^{\text {th }}$ book where the battle between Antigonos and the Celts is mentioned, Trogus simply says defectores Galli. That they were from Gallograecia is mentioned only by Justin. ${ }^{56}$ Now in Justin the name occurs three times - once in the $25^{\text {th }}$, once in the $26^{\text {th }}$ (that is in the chapter un-

${ }^{50}$ Plut., Aem. Paul., 9.4.

$51 A E$ 1960: no.76, an inscription from Olympia where a number of men from Achaia who fought under Cn. Domitius Ahenobarbus against the Galatai are recorded. He is almost certainly the consul in 122 who fought against the Salluvii, the Allobroges and the Arverni. see J. Reynolds (1961): "Roman Epigraphy, 1961-65", JRS 56, 118; BE 1959, 189; T. R. S. Broughton (1951): The Magistrates of the Roman Republic vol.1, New York, 516.

${ }^{52}$ F. W. Walbank (1959): A Historical Commentary on Polybius vol.1, Oxford, 49.

${ }^{53}$ D. R. J. Campbell (2009): The so-called Galatae, Celts, and Gauls in the Early Hellenistic Balkans and the Attack on Delphi in 280-279 BC (Thesis submitted for the degree of Doctor of Philosophy at the University of Leicester), 138.

@ https://lra.le.ac.uk/bitstream/2381/4550/1/2009campbelldrjphd.pdf

54 There is no need to get into the complex problem of Trogus' sources; for a convenient introduction with the essential bibliography see Heckel 1997: 30ff.

55 I have made no attempt for a comprehensive research into every single occurrence of the name, and confined myself to some 40 examples. After all it is not my intention to challenge the view that the name Gallograecia is used exclusively for the Celtic territory in Asia Minor.

${ }^{56}$ One would be tempted to cast the blame for the possible error on Justin rather then Trogus, if not for Liv., 33.18.3 where it is obvious that under the name Galli he means the Celts from Asia Minor. Therefore we can not be certain whether Trogus used the name in a general sense or he meant the Celts from Asia Minor. 
der discussion) and once in the $38^{\text {th }}$ book. In the $25^{\text {th }}$ book he describes the arrival and settling of the Celts in Asia Minor and the name is obviously used properly. However, the use of the word in the $38^{\text {th }}$ book is far more interesting: Post haec Mithridates intellecto quantum bellum suscitaret, legatos ad Cimbros, alios ad Gallograecos et Sarmatas Bastarnasque auxilia petitum mittit. ${ }^{57}$ Now the pairing of these Gallograeci with the Cimbri, Sarmatae and Bastarnae, undoubtedly shows that in this case we are dealing not with the Celts from Asia Minor but the Balkans, and this has been recognized long ago. ${ }^{58}$ It goes without saying that just one such example is not nearly enough to insist that Justin made the same mistake in the $26^{\text {th }}$ book as well, but at the same time does leave the door open for such an assumption, and in any case casts additional doubt in Justin's already problematic description.

If in fact we are dealing with Celts from the Balkans, this would come as no surprise. After all, the rulers who had made the greatest capital from defeating the Celts were also the first to enlist them in their armies, ${ }^{59}$ and Antigonos was no exception. After the battle of Lysimacheia he hired a large body of Celts, and used them during his fight for the Macedonian throne. ${ }^{60}$ Few years later, in the battle against Pyrrhos already mentioned above, it was the rearguard comprised of a numerous body of Celts that fought loyally to the bitter end. ${ }^{61}$ Therefore, if Antigonos was in need of a body of Celtic mercenaries during the Chremonidean War, he would hardly have needed Antiochos' help - not only did he already had a whole decade of experience in dealing with the Celts, but also there were plenty of them in the Balkans who could be hired and put into action much faster. Therefore, though nothing can be said with certainty, it does seem possible that just like in the $38^{\text {th }}$ book, when Justin speaks of Gallograecia we are not dealing with the Galatians from Asia Minor, but the Celts from the Balkans.

4. It is time to summarize the arguments. The epitaph of Brikkon, that was to be the most important and certainly decisive argument, as was shown almost half a century ago is from a later date and therefore can not be used in the discussion concerning the assistance provided by Antiochos I during the Chremonidean War. The presence of the elephants on the other hand, though in-

57 Just., 38.3.6.

${ }^{58}$ D. Magie (1950): Roman rule in Asia Minor, vol.2, Princeton, 1235 n.38; Papazoglu 2007: 266 n.6.

${ }^{59}$ Mitchell 2003: 288. For the presence of the Celts in the Hellenistic armies see M. Launey (1949-50): Recherches sur les armées hellénistiques, 2 vols., Paris.

${ }^{60}$ Polyaen., 4.6.17.

${ }^{61}$ Plut., Pyrrh., 26.3. 
triguing at first glance, is far less surprising once it is established that Antigonos still had some in his army prior to the beginning of the war. The suggestion that they were send by Antiochos I becomes even less convincing if we take into account the possibility that the situation in Asia Minor may not have been as settled as it might seem, and even more importantly, that he may not have even had a large number of elephants at his disposal at the time. Without these two arguments, the problematic description in Justin of the battle between Antigonos and the Gallograeci at best could be used as an indication but not as a proof; and even in that case, there is a possibility that we are dealing with Celts from the Balkans and not Asia Minor.

In short, there is not a single piece of evidence that compels us to accept that Antigonos received any help from Antiochos I during the Chremonidean War. Of course it would be naïve to think that this settles the matter once and for all, nor was that my intention. There are too many blanks in our knowledge for this period, too many ifs and maybes to be certain of anything. Yet I hope to have shown that the theory about the participation of Antiochos I in the Chremonidean War rests on a far less persuasive arguments than it might seem at first, and in a way that is enough. For the burden of proof rests on those scholars who think that Antiochos I did indeed send some kind of help to Antigonos, and until some new and more persuasive argument can be brought in the discussion, it would be better to assume that Antiochos I stood aloof from the war. 